\title{
2 Timothy 4:6-8 as Paradigm of the Apostle Paul's Legacy
}

\author{
By Luc Bulundwe*
}

\begin{abstract}
This study aims to demonstrate that, in the New Testament, the second letter to Timothy moulds the figure of Paul as one of the most influential figures in early Christianity. By doing so, the epistle would have the potential to shape Paul's figure on the whole Corpus Paulinum. The originality of this paper lies in the consideration of the Pastorals as a differentiated unity that offers to analyse 2 Tim without 1 Tim and Titus, as a fictive Pauline farewell discourse. Using intertextuality, it compares 2 Tim with Phil, a Proto-Pauline letter, in order to emphasise the shift from Pauline to DeuteroPauline literature. The first one considering Paul's death as an upcoming event, whereas the latter considers Paul's work from a seemingly a posteriori stand point. On the one hand, Phil depicts Paul as a potential perfect follower of Jesus. On the other hand, 2 Tim moulds the figure of Paul as the one and only apostle, building, with the literary genre of farewell discourse, Pauline "orthodoxy". Thus, the purpose of 2 Tim and the Deutero-Pauline letters seem to be to fill a gap in the description of Paul's legacy. Hence, the particular interest of this paper is to consider the possible influence of 2 Tim in the entire Pauline literature.
\end{abstract}

Keywords: Deuteropaulinism, Farewell discourse, New Testament studies, Pauline literature.

\section{Introduction}

History has proven over the centuries that no master's legacy has lived on without disciples. Plato and Socrates are certainly the best of such examples at the end of the Age of Pericles. The New Testament confirms this statement as all the four Gospels present Jesus of Nazareth's call for disciples as a significant phase of his ministry (cf. Mk 2:13-17; Mat 9:9-13; Lk 5:27-32; Jn1:35 et sqq). This is the well-known "following Christ" theological concept, which in the canon, reaches its climax in the work of the Apostle Paul. Although he was not one of the Twelve, indeed in the New Testament Paul of Tarsus is depicted as one of the most faithful followers of the person he does not hesitate to call Christ Jesus. In his epistolary writings, the Apostle of the nations clearly develops, more than anywhere else, the imitatio Christi and even goes as far as moulding it through the lens of his own self to develop an imitatio Pauli (cf. 1 Cor 11:1). At the climax of this concept, Paul mentions his death in sacrificial terms as he writes to the Philippians by referring to selfsacrifice by libation (Phil 2:17). He reveals his last wishes during what he perhaps considered the threshold of his life, in captivity. But in any event, did the Apostle of the nations really end up being poured out as a drink offering?

${ }^{*} \mathrm{PhD}$ Student, University of Geneva, Switzerland. 
Did he follow Christ's footsteps and allow himself to be sacrificed? What does his work say about the Apostle's legacy?

The so-called "Deutero-Pauline" (Vouga 2008a: 163) ${ }^{1}$ literature is replete with answers to these questions. It illustrates how the disciples interpreted Paul's work in the new historical context in which they were. With regards to his death, and therefore his legacy, 2 Tim undoubtedly stands as one of the most interesting texts as it specifically points out some "testamentary traits" (Redalié 2008a: 332). The use of the testamentary literary genre suggests that the author of the text aimed at creating an "orthodox" tradition (Redalié 1994: 37) ${ }^{2}$ within the plurality of Pauline Christianity which characterised the post-apostolic

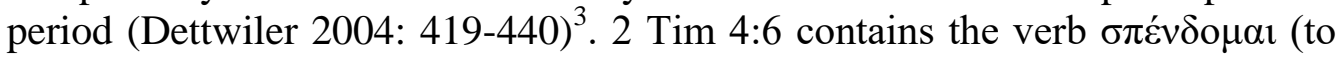
be poured out as a drink offering) already used in Phil 2:17. However, rather than making reference to the Apostle's death as a possible upcoming event, it underscores an already experienced reality ( $\left.\eta^{\prime} \delta \eta\right)$. As such, this excerpt paradigmatically resumes Paul's work from a seemingly a posteriori stand point. This is typical of the shift from Proto-Pauline to Deutero-Pauline literature whose consequences relate especially to the reactions towards the historic figure of Paul. His disciples did not only re-use the figure of the Apostle of the nations to explain their context, but at the same time, also redirected the reading of the Proto-Pauline letters and in this case, that of the epistle to the Philippians.

To illustrate this hypothesis, this study shall in the first place analyse the context in which 2 Tim was written in a bid to provide insight into how its author presented the issue of the Pauline legacy. This shall include, among other things, locating the epistle within the corpus of the Pastoral Epistles and examining the literary genre of 2 Tim. Then, it shall interpret 2 Tim 4:6-8 specifically, as it contains the testamentary trait which is most typical of the epistle by comparing it with Phil 2 to determine how Deutero-Pauline literature can influence Proto-Pauline literature.

\footnotetext{
${ }^{1}$ Vouga showed that Paul's letters, like other ancient collections of letters especially those of Epicurus, were not solely written by him. They were part of a literary work written in school under the authority of a master of thought, who was in this case Paul. Therefore, they must not all be considered as historically true stricto sensu. In the New Testament, out of the thirteen letters written by Paul, seven have been certified today as being authentic (Rom 1 and 2 Cor, Galatians, Phil 1, Thess and Phil) while the other six (Eph, Col, 2 Thess and the three Pastoral Epistles) are mostly considered pseudepigraphic writings. Although discussions have been revived today for $\mathrm{Col}$ and $2 \mathrm{Tim}$, amongst others. Vouga explains that the aim of pseudepigraphic literature is "to bring the philosopher's or apostle's word to life in the new times".

${ }^{2}$ Redalié already examined this hypothesis developed around the German exegetical school formed by Peter Trummer (1978), Jürgen Roloff (1988), Michael Wolter (1988) and later by Annette Merz (2004).

${ }^{3}$ Dettwiler underscores that the Pauline school must be considered in its plurality, according to different "wings" and having disciples which may be more advanced than others.
} 


\section{The Pastoral Epistles: A Differentiated Unity}

Since the 19th century at least, 2 Tim has been traditionally read and interpreted in conjunction with the two other so-called Pastoral Epistles, 1 Tim. and Titus, following the exegetic hypotheses formulated by German exegetes (Klauck 2006: 324). However, the tone had already been set by Augustine's writings in the 4th century, and even before, according to the analysis of the Muratorian canon in which some have also pointed out the "ecclesial concern" (Redalié 2008a: 329) which is common to the Pastoral Epistles. As a result of this first finding, the Pauline authenticity of the pastoral letters was questioned in the works of Schleiermacher, Baur or Holtzman whose 1880 comment has become a classic text. However, this unanimous point of view was called into question. Today, some commentators suggest dropping the qualifier "Pastoral" (Bénétreau 2007: 13) ${ }^{4}$ to avoid the numerous misunderstandings it causes between the specific features of the three epistles.

Therefore, if it is not possible to totally call into question the Pastoral corpus - like some biblical scholars ${ }^{5}$ - as the homogeneity of the corpus cannot be totally called into question (Collins 2002: 177-180) ${ }^{6}$, we believe that 2 Tim presents a specific situation which requires a specific tone (Collins 2002: 185). Hence, the three Pastoral Epistles can be usefully interpreted through the lens of their own demands (Herzer 2004: 1280). For 2 Tim, they are reflected in the testamentary literary genre chosen for its writing and characteristic of a transitional period.

\footnotetext{
${ }^{4}$ For Bénétreau the term makes it impossible to drown the epistles in a large entity and highlights their specific contributions. On the other hand, Johnson (2001: 63-64) postulates that regrouping the three epistles in a corpus called pastoral skews the historical analysis of the letters by attributing the characteristics of some to others. Fuchs (2003: 175) goes further by titling his fourth chapter: Abschied von "den" Pastoralbriefen and Towner (2006: 88-89), translates this same title for one of his paragraphs: "Farewell to the Pastoral Epistles" and proposes to regroup the three letters to avoid any restrictive intertextual relation. Finally, Gourgues (2009: 41-42) states that in 1901 a certain J. Moffat had already noted a potential misunderstanding. Gourgues also doubts the relevance of this title for semantic reasons. The

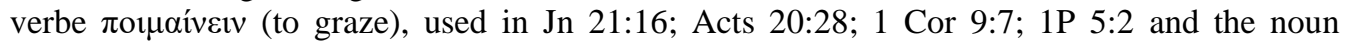
$\pi$ ou $\mu$ v $v$, which means shepherd (Eph 4:11; 1 P 2:25) are not in the Pastoral Letters.

${ }^{5}$ Richards (2002) puts forward one of the strongest arguments for fragmenting the corpus. He proposes to split the three epistles into three respective authors.

${ }^{6}$ Collins believes that 2 Tim stands out from the two other Pastorals in terms of its literary genre and based on semantic and lexical markers. While 2 Tim represents an attempt to answer the following question: "who" can legitimately continue Paul's work? 1 Tim and Titus attempt to express: "how" should the community be organised? Therefore, what would link the corpus would be the intrinsic proximity of these two questions. According to this hypothesis, 2 Tim legitimises Paul's successor who would implement the program presented in 1 Tim and Titus. Other commentators highlight the connection between the Pastoral letters by warning of the risk involved should it be severed if it was broken. As such, according to Wolter (1988: 240), the Pastoral Epistles must be read while bearing in mind that they constitute a corpus. He however emphases that based on the making of the scriptures, 2 Tim comes after 1 Tim and Titus and has a different purpose. The last epistle is more of an exhortative text which is used to repeat and synthesise some purely exhortative parts developed in the others epistles.
} 


\section{A Literary Genre for a Time of Crisis}

Many commentators have identified 2 Tim as belonging to the testamentary literary genre (among others: Wolter 1988, Weiser 2003, Redalié 2008a). In this text, Paul presents himself as having "fought the good fight" and "finished the race" by keeping "the faith" (cf. 2 Tim 4:7). Moreover, he paints himself, as well as Timothy, as following an ancestral family (cf. 2 Tim 1:3,5) which is striving to guard the "good deposit" that "was entrusted" to it (cf. 2 Tim 1:14) and which was entrusted to Paul by God (cf. 2 Tim 1:12). Our epistle presents the transfer of a legacy of faith which precedes Paul and is meant for at least three generations after him (cf. 2 Tim 2:2).

Between $2: 8$ and 4:5, there are no fewer than 18 singular imperatives: "remember", "keep reminding", "avoid", "do your best to", "flee", "preach", "rebuke", "encourage", "endure hardship", etc. The list starts with the order to remember ( $\mu \nu \eta \mu$ ovev́ $\omega)$. The past is mentioned in the form of a family history (cf. 2:8). Then on two occasions, the future is referred to: "But mark this: There will be terrible times in the last days" (3:1); "For the time will come [...]. But you, keep your head in all situations, endure hardship, do the work of an evangelist, and discharge all the duties of your ministry (4:3-5). In both cases, these parts which we can consider eschatological are followed by a description of the difficulties to come, using the third person plural $(3: 1-5 \mathrm{a} ; 4: 3-4)$. We are already experiencing some signs of these difficulties (3:5b-9). An exhortation to Timothy closes each of these parts by using the singular imperative again: "But as for you..." (3:10-14; 4:5). The imperative which is used throughout the body of the letter highlights the personal tone of the epistle. In addition, the call to "remember" in 2:8 and the movement between the signs already present and the eschatological future show that the epistle's narrative framework is typical of a transitional situation, a crisis period which explains the choice of the testamentary literary genre.

It is true that 2 Tim is first and foremost an epistle and that the qualifier of testament must absolutely be nuanced (Wolter 1988: 222) ${ }^{7}$. However, in ancient times, the use of one literary genre did not necessarily exclude the use of other genres. For instance, Epicurus' epistolary legacy reported by Diogène Laërce (book X, 22) is a testament written in the form of a letter of friendship. The tone used in 2 Tim is more personal than that used in 1 Tim and Titus and brings it closer to the personalia (Collins 2002: 182). Furthermore, even as testaments are concerned, there is a difference between literary and historical tributes. That is what Bornkamm (1993: 111) puts forward with the letter to the Romans. This is not a testament in the strict literary sense, but from a historical perspective, which comes in at an advanced stage of Paul's ministry and which carries a synthetic dimension of his thoughts.

Through an inter-textual analysis, Collins shows that the testamentary literary genre comprises other types of forms such as parenesis, apocalyptic literature or midrashim (Collins 2002: 182-183). The exegete specifies that the

\footnotetext{
7 Having considered these nuances, Wolter (1988: 236) states that the inter-relationship between 2 Tim and testamentary literature is obvious.
} 
farewell speeches present a hero of the past who is gathering his family and closest friends around him as he faces death. He recalls his past accomplishments by highlighting a mistake or an unfinished work on which he urges his close friends to work after he leaves. As such, his close friends become the bearers of a tradition he started. Given that the main protagonist is presented as a hero about to die, "his" writings are sometimes not the product of his hand, but the works of a very close disciple. These observations may apply to $2 \mathrm{Tim}$ as we previously tried to demonstrate. Historically, a post-Pauline context coincides not only with the narrative framework of the epistle but equally with the semantic that figures in $2 \mathrm{Tim}$. As an example, we shall mention the topos of

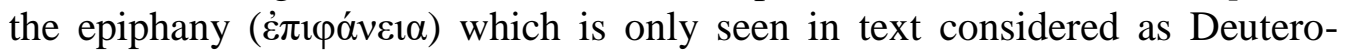
Pauline (replacing the $\pi \alpha \rho o v \sigma i \alpha$ context?). In this case, what is the purpose of summoning the Apostle of the nations? To understand this, the issue of the authorship of the epistle, which is widely debated in research, must be addressed.

\section{Construction of a Pauline "Orthodoxy"}

\section{Tm-Terminus Ad Quem of the Pauline Corpus}

In spite of the fact that this consensus (Herzer 2004: 1267-1282) has faded away in the history of the Pastorals research, the epistle is still widely considered as post-apostolic. The interpretative group in favour of pseudonymy still comprises, for the most part, German exegetes (Trummer, Wolter, Merz), followed in the French-speaking literature by Redalié, among others. They believe that the author is part of a third generation of Christians (Vouga 2008a: $165)^{8}$. The supposed recipient of the epistle would in fact be the authors. In this perspective, the intertextual relationship of the three Pastoral Epistles and their sources, the Proto-Pauline epistles, reveals not only their author's prerogatives but most especially the way in which one of the classes of the Pauline school (Dettwiler 2004: 439-440) has re-interpreted Paul's work and the Sitz im Leben which motivated him to do so. The author fictitiously refers to Paul and his most faithful co-workers at that time (cf. 1 Thess $1: 1 ; 1$ and 2 Co 1:1 ; Phil 1:1 ; Phm $1 ; 1$ Co $4: 17 ; 16 ; 10 ; 1$ Thess 3:2-3 ; Phil 2:20-22) to re-interprete his work and create a tradition in a radically new context. As such, Redalié (2008b: 600) in his translation of Merz states that:

"Through this device, when faced with competing interpretations the author of the pseudepigraphy may set, guide and update the meanings of Pauline reference texts. Pseudepigraphy is therefore used to fight for Paul's legacy in a context characterised by conflicting interpretations. Fictitious "self-referencing" is a literary weapon, an inter-textual mode for the

\footnotetext{
${ }^{8}$ Vouga discusses the Trito-Pauline concept. This designation has become popular today. As earlier emphasised, this study only discusses the Deutero-Pauline concept in line with the works of Dettwiler and taking into consideration the nuances brought in the history of research on 2 Tim.
} 
construction of meaning aimed at depriving competing interpretations of their gall to present themselves as Paul's legacy".

According to Merz (2004), 2 Tim may be considered as Paul's main and true legacy. Whether its author was Paul on his deathbed, Timothy writing at his bedside or much a more recent author, he would have as an aim to strengthen the influence of the tradition dating to Paul the apostle, to support education in the Christian faith, improve ministerial structures and fight a form of heresy that seems to have threatened the recipient communities, including within the Pauline community as we highlighted above. If we add that the author certainly chose the testamentary literary genre to make 2 Tim a potential terminus ad quem of the Corpus Paulinum, the observation is all the more striking. The way Paul discusses how he faces death must be studied in Proto-Pauline literature and in $2 \mathrm{Tim}$. It reveals, in the light of the diachronic analysis conducted above for 2 Tim, a finding of a posteriori construction.

\section{A Posteriori Construction of an Exemplary Figure}

2 Tim 4:6-8 may seem too short to be considered a pericope. Indeed, these three verses cannot be isolated from the rest of chapter 4 and especially chapter $4: 1-5$, if we refer to the inclusio between the mention of the epiphany (v. 1) and that of "on that day" (v. 8); two eschatological references. However, there are differences between these three verses. First, they are written in the first person singular immediately after a more exhortative section addressed to Timothy. Therefore, they reflect on the figure of Paul. However, as Collins (2002: 265) underscores, if the entire pericope is placed under the sign of the announcement of Paul's departure, the first part is centered on recommendations addressed to Timothy (verses 1 to 5) depending on his master's departure, introduced in verses 6 to 8 with the emphatic marker: $\dot{\varepsilon} \gamma \dot{\omega}$. Then the Apostle of the nations states that "his" departure is imminent and that Timothy must be his successor. If Paul is omnipresent in this passage, as a "key figure", he is on his way out, not to say absent, from a historical stand point. He is presented at the threshold of his life.

Paul's death is presented in a sacrificial language reminding some references of the veterotestamentary canon (cf. Ex 29:40; Num 15:5; 28:7; 2 Rom 16:13;

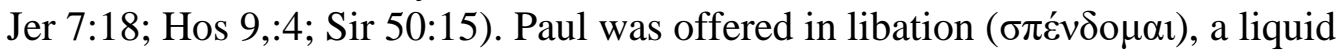
offering mostly made to a god or pegan deities, for example in the GraecoRoman world. This could be wine before the meal or in between the meal and the speech during official celebrations. This imagery could be specific to both Judaeo-Christian and pagano-Christian environments. In the Apostle's writings, the cultural and sacrificial imagery are made in reference to the Christ (cf. Rom 3:25; 1 Cor 5:7) and to designate his own ministry (cf. Rom 15:16) or for the service that others offered (cf. Rom 12:1; 15:27; 2 Co 9:12; Phil 2:25; 4:18). The same reference is made by Paul for his own life in Phil 2:17 $(\sigma \pi \varepsilon \dot{\varepsilon} \delta \circ \mu \alpha \imath)$ and it seems to be the main intertextual reference of $2 \mathrm{Tim}$. As a matter of fact, in Phil 2:16, the reasons for the race ( $\delta \rho o ́ \mu о \varsigma)$, of 2 Tim 4:7, 
appears in the aorist form of $\tau \rho \varepsilon \dot{\chi} \omega$, है $\delta \rho \alpha \mu \nu v$. Furthermore, the promise of sending Timothy to the Philippians immediately follows in Phil 2:19-24. In addition the prison context is common to both epistles. But what does it mean to be poured out as a drink offering? There is no doubt that the veterotestamentary and pagan contexts remind, at the backdrop, of the idea of sacrifice. According to Reumann (2008: 415), Phil 2:17 could be a reminiscence of the motif of the agon, which further highlights the connection to 2 Tim 4:6-8. It could also refer to self-sacrifice which Paul has undertaken since he got involved in the "apostolic ministry" and specifically his "missionary experience". It should be noted that the reference to the day of Christ ( $\dot{\eta} \mu \varepsilon \dot{\varepsilon} \rho \alpha$ X $\rho 1 \sigma \tau o \tilde{u})$ in Phil 2:16 denotes an eschatological context which is also present in 2 Tim 4:6-8 with the

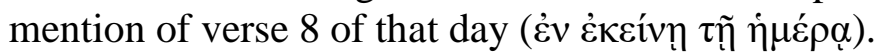

Looking back on the notion of drink offering in 2 Tim 4, Paul seems to be both sacrifice and priest whereas in Philippians, this is not that obvious. He emptied himself for the recipient community and therefore becomes a redeeming figure. He offered himself as a libation for their sake. In 2 Tim, this is not evident. Did Paul risk his life to preach and teach the Gospel (cf. 2 Tim 4:5)? What is obvious is that Paul has now finished his work. That is the meaning behind the word $\eta \delta \eta$ (already). Paul is already being poured out like a drink offering. In other words, his sacrifice shall not be carried out by him but by his successors who shall follow his steps (i்o the possibility to be one day offered as a drink offering, in Tim, the offering is consumed in the form of imprisonment (2 Tim 1:8.16;2:9) and suffering $(1: 8 b .12 ; 2: 9)$ which must lead to the transfer of legacy and even to death. The emphasis laid on the transfer of legacy is sustained by four verbs in the perfect

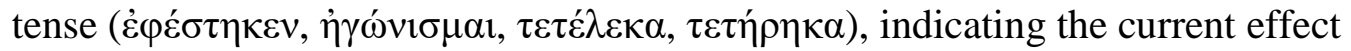
of a past action.

In Phil 1:23, Paul states he wishes to depart and be with Christ (zis tò

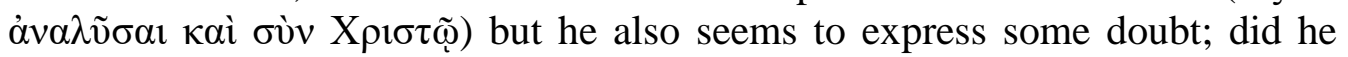
still have some work to do? In any case, there is a general feeling that this imprisonment is not permanent. This doubt seems to be totally cleared up in 2 Tim 4:6-8. Paul is departing! Consequently, the author could have chosen to work with the letter to the Philippians as an intertext, to ensure that the exemplary image of Paul at the threshold of death lives on. Besides, some authors have not hesitate to qualify 2 Tim 4:6-8 as a "re-writing of Phil 2:16-17 in the light of Paul's martyrdom" (Gourgues 2009: 333). Paul of Tarsus is poured out as a drink offering, as he had predicted. The context highlighted here is that of the exemplary conduct of the Apostle Paul (Vouga 2008b: 253). Also, in 2 Tim 4:7, various images used by Paul when he was alive are repeated and presented as his accomplishments. Both images provide some sort of ideal retrospective review of Paul's life as it appears in the Pastoral Letters. He encouraged Timothy to fight the good fight (1 Tim 1:18; 1 Tim 6:12). If he encourages his followers to do same, it is because he himself had to go through this trial, the good fight.

"At the threshold" of Paul's death, and if we look back on the main intertext of 2 Tim 4:6-8, that is Phil 2:16-17, Merkel (1991: 82) underscores that in Paul's 
writings, his future could not be predicted in such admiring terms (cf. Phil 3:1214). There, Paul was rather presenting himself as one of the heirs of salvation, amidst others who do not yet have the price of victory. In 2 Tim 4:6-8, Paul became the ideal-epitome which Timothy, who represents the followers, is encouraged to resemble. As Albert Schweitzer pointed out, the best way to influence others is by example. Therefore, the auctor ad Timotheum undoubtedly aimed at filling a gap in Proto-Pauline tradition. The latter never presents a detail account of Paul's death. On the other hand, the author of 2 Tim gives the impression that he is imposing the traits of Paul as a figure to ensure his legacy in the plural context of the new Christian tradition. As such, this short pericope may be considered, in our view, as the paradigm of the Pauline legacy.

\section{Conclusion: "A Testament within the Testament"9}

The starting questions focused on the disciples' response to Paul's work as well as the sacrificial description of the Apostle's death as he was poured out like a drink offering. Our analysis reveals that although it is possible to state that part of the response to Paul has kept his memory alive today, it is clear that the context in which the image of the drink offering appeared seems to be constructed. The auctor ad Timotheum, whether he was one of his closest disciples obeying the last wishes of the Apostle of the nations or a more recent author, seems to aim at filling a gap of Proto-paulinism regarding the Pauline legacy. A posteriori, it answers the question as to how Paul departed, what assessment he made of his work and most especially, how he passed the torch of the Gospel of Christ to his successors. For that purpose, it constructs a Pauline "orthodoxy" by laying emphasis on the figure of Paul with a sole focus

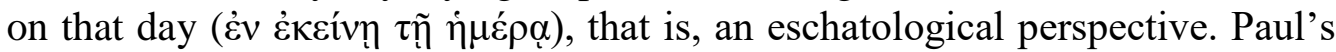
heirs are not forgotten as 2 Tim 4:8 specifies that Paul's reward shall be shared with "all who have longed for his [the Lord's] appearing ( $\tau \grave{\eta} v \dot{\varepsilon} \pi \iota \varphi \alpha ́ v \varepsilon 1 \alpha v$

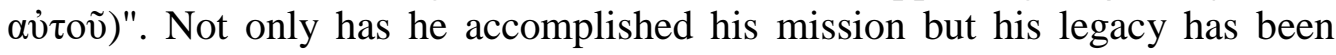
established. In Proto-Pauline literature, Paul did not dedicate any section to his legacy. In his writings, he always showed his forthcoming projects, what he was still determined to accomplish, mainly in the missionary field. This is clearly seen in his letters to the Philipians and the Romans. In addition, due to the analysis of the Pastoral Letters as a differentiated unit, this study was able to remind that the influence of 2 Tim may cover the entire Corpus Paulinum. The author of 2 Tim carved Paul's image thereby contributing to making him an inescapable figure of post-apostolic Christianity and 2 Tim 4: 6-8 "the testament within the testament" of the Apostle of the nations.

\footnotetext{
${ }^{9}$ Weiser (2003: 298).
} 


\section{Acknowledgments}

Our thanks to Calen Gayle for his rereading and, last but not least, many thanks for the precious advices to professor Andreas Dettwiler under whose supervision I wrote my master thesis on the second letter to Timothy.

\section{References}

Bénétreau S (2007) Les épîtres pastorales: 1 et 2 Timothée, Tite [The Pastoral epistles: 1 and 2 Timothy, Titus]. Vaux-sur-Seine, France : Édifac.

Bornkamm G (1993) Paulus [Paul]. Stuttgart, Germany: Kohlhammer.

Collins RF (2002) 1 \& 2 Timothy and Titus: a commentary. Louisville: Westminster J. Knox Press.

Dettwiler A (2004) L'école paulinienne: évaluation d'une hypothèse [The Pauline school: evaluation of a hypothesis]. In JD Kaestli, D Marguerat (Eds) Paul, une théologie en construction (419-440). Geneva, Switzerland: Labor et Fides.

Fuchs R (2003) Unerwartete unterschiede. Müssen wir unsere Ansichten über die Pastoralbriefe revidieren? [Unexpected differences. Do we have to review our views on the pastoral epistles?]. Wuppertal, R. Brockhaus Verlag GmbH \& Co.

Gourgues M (2009) Les deux lettres à Timothée: La lettre à Tite [The two letters to Timothy: The letter to Titus]. Paris: Les Éditions du Cerf.

Herzer J (2004) Abschied vom Konsens? Die Pseudepigraphie der Pastoralbriefe als Herausforderung an die neutestamentliche Wissenschaft [Farewell to the consensus? The pastoral epistles pseudepigraphy as challenge to new testament studies]. Theologische Literaturzeitung 129: 1267-1282.

Johnson LT (2001) The first and second letters to Timothy: A new translation with introduction and commentary. NY: Doubleday.

Klauck HJ (2006) Ancient letters and the New Testament. A guide to context and exegesis. Waco (Texas): Baylor University Press.

Merkel H (1991) Die Pastoralbriefe [The Pastoral Epistles]. Göttingen, Germany, \& Zürich, Switzerland: Vandenhoeck \& Ruprecht.

Merz A (2004) Die fiktive selbstauslegung des Paulus: Intertextuelle studien zur intention und rezeption der Pastoralbriefe [The fictitious self-exposition of Paul: Intertextual studies on the intention and reception of the Pastoral Epistles]. Göttingen, Germany: Vandenhoeck \& Ruprecht.

Redalié Y (1994) Paul après Paul: Le temps, le salut, la morale selon les épîtres à Timothée et à Tite [Paul after Paul: time, salvation, morality according to the epistles to Timothy and Titus]. Geneva Switzerland: Labor and Fides.

Redalié Y (2008a) Les épîtres pastorals [The pastoral epistles]. In D Marguerat (Ed) Introduction au Nouveau Testament (329-348). Geneva, Switzerland: Labor et Fides.

Redalié Y (2008b) Le rôle de la figure de Paul dans la théologie des épîtres pastorales [The role of Paul's figure in the pastoral epistles' theology]. Revue Biblique 115(4): 596-612.

Reumann J (2008) Philippians: A new translation with introduction and commentary. New Haven - London: Yale University Press.

Richards WA (2002) Difference and distance in post-pauline christianity: An epistolary analysis of the pastorals. NY: Peter Lang.

Towner PH (2006) The letters to Timothy and Titus. Grand Rapids: Eerdmans. 
Vouga F (2008a) Le corpus paulinien [The pauline corpus]. In D Marguerat (Ed) Introduction au nouveau testament: Son histoire, son écriture, sa théologie (161178). Geneva, Switzerland: Labor and Fides.

Vouga F (2008b) L'épître aux Philippiens [The epistle to the Philippians]. In D Marguerat (Ed) Introduction au nouveau testament: Son histoire, son écriture, sa théologie (251-264). Geneva, Labor and Fides.

Weiser A (2003) Der zweite brief an Timotheus [The second letter to Timothy]. Düsseldorf, Germany, \& Zürich, Switzerland: Benziger Verlag - NeukirchenVluyn, Neukirchener Verlag.

Wolter M (1988) Die pastoralbriefe als Paulustradition [The pastoral epistles as Pauline Tradition]. Göttingen, Germany: Vandenhoeck \& Ruprecht. 